Безпосередньо в Київському навчальному окрузі протягом розглянутого дворіччя відбувалося поступове введення правил, єдиних для інших округів імперії, проходив процес нівелювання відмінностей між навчальними закладами Київського округу порівняно з іншими російськими округами. Ці документи важливі дія істориків, оскільки вони характеризують політику, яку проводила Російська імперія на українських землях після придушення польського повстання 1830-1831 рр., коли більшість польськомовних навчальних закладів закрили, їх відкриття супроводжувалося введенням жорсткіших правил контролю та нагляду. Лібералізм періоду візитаторства Ф. Чацького та панівного становища у регіоні польської культури змінився на виховну систему, девізом якої була відома формула С. Уварова «самодержавство, православ'я, народ». Загалом Київський навчальний округ поступово входив до єдиної державної системи освіти, зазначені укази та циркуляри мали всіляко сприяти такому процесу.

\title{
Література
}

1. Рождественский С. В. Исторический обзор деятельности Министерства Народного Просвещения / С. В. Рождественский (1802-1902). - СПб., 1902. 2. Шевелев А. Н. Школа. Государство. Общество. Очерки социально-политической истории общего школьного образования в России второй половины XIX века / А. Н. Шевелев. - СПб., 2001. 3. Журнал министерства народного просвещения. 1834. -№1, январь. 4. Журнал министерства народного просвещения. - 1834. - № 2, февраль. 5. Журнал министерства народного просвещения. - 1834. - № 4, апрель. 6. Журнал министерства народного просвещения. - 1834. - №8, август. 7. Журнал министерства народного просвещения. 1834. - № 7, июль. 8. Журнал министерства народного просвещения. - 1834. - №6, июнь.

\section{ТЛУМАЧЕННЯ ДЕФІНЦІЇ «КРИТИЧНЕ МИСЛЕННЯ»: ІСТОРИЧНИЙ ЕКСКУРС}

Краснолуцький К. К. Тлумачення дефініції «критичне мислення»: історичний екскурс.

У статті аналізується поняття «критичне мислення». Розглядаються історія розвитку й еволюція дослідження поняття «критичне мислення», основні етапи розвитку критичного мислення й оцінювання його рівнів розвитку в науковій літературі. Здійснено аналіз дефініції на сучасному етапі: 1) психологічна готовність розглядати вдумливо проблеми і питання, що входять до спектру власного життєвого досвіду; 2) знання методів логічного дослідження й аргументації; 3) наявність певних навичок у застосуванні цих методів.

Ключові слова: мислення, критичне мислення, творче мислення, етапи розвитку критичного мислення.

Краснолуцкий К. К. Толкование дефиниции «критическое мышление»: исторический экскурс.

В статье анализируется понятие «критическое мышление». Рассматривается история развития и эволюция исследования понятия «критическое мышление», основные этапы развития критического мышления и оценки его уровней развития в научной литературе. Подан анализ дифиниции на современном этапе: 1) психологическая готовность рассматривать вдумчиво проблемы и вопросы, которые входять в спектр собственного жизненного опыта; 2) знание меодов логического исследования и аргументации; 3) наявность определенных навыков в применении этих методов.

Ключевые слова: мышление, критическое мышление, творческое мышление, этапы развития критического мышления.

Krosnolutskiy K. K. Interpretation definitions of «critical thinking»: historical background.

The article analyzes the concept «critical thinking». The history of the development and evolution of the study of "critical thinking», the main stages in the development of critical thinking and evaluation of its development levels are considered in the scientific literature. At this stage there was made the analysis of definitions: 1) psychological readiness to consider carefully the issues and questions that are part of the own life experience, 2) knowledge of the methods of research and logical reasoning 3 ) the presence of certain skills in these methods application.

Key words: thinking, critical thinking, creative thinking, critical thinking development stages. 
У сучасному світі, що стрімко змінюється, розкриваючи при цьому як нові можливості, так і зумовлюючи нові загрози, виникла нагальна потреба у перегляді сучасного світосприйняття, перебудови нашої свідомості, яка б забезпечила суспільству комфортне існування в умовах постійного дискомфорту. У світі виник вражаючий дисонанс між експонентним розвитком сучасних технологій і неготовністю суспільства до кардинальних змін у своїй свідомості. Такий стан речей насамперед пов'язаний із застарілими моделями розвитку мисленнєвої діяльності, які передбачають запам'ятовування й утримування певної інформації. Такий підхід довів свою хибність і більше не може слугувати гарантією подальшого прогресу як окремо взятої особистості, так і суспільства загалом. На сучасному етапі державотворення в українському суспільстві, побудови громадянського суспільства в Україні імперативом постає культивування і всебічне сприяння вихованню уміння критично мислити, об'єктивно оцінювати різноманітні явища, процеси, події. Критичне мислення стане запорукою динамічного розвитку українського суспільства. Населення України, і насамперед молодь, має опановувати прийоми критичного мислення. На жаль, освіта відстала від швидкого науковотехнічного прогресу. Уява та мислення поки що залишаються акторами із другорядними ролями в сучасній навчальній діяльності. Аби виправити цю аномальну ситуацію, необхідно активно пропагувати самостійне, продуктивне мислення, яке стає основною вимогою для нового покоління наукової і бізнесової еліти.

Динамічне, самокероване, самодисциплінуюче, самокорегуюче мислення стає не тільки бажаним, але й конче необхідним атрибутом не тільки успіху, а й виживання в цьому жорсткому, небезпечному, але й одночасно прекрасному світі.

Елементи критичного мислення можна спостерігати в наукових працях сучасних вітчизняних науковців. Різні аспекти цієї проблеми розглядали А. Алексюк, Л. Арістова, С. Архангельський, Ю. Бабанський, Д. Богоявленська, М. Ігнатенко, О. Матюшкін, Н. Менчинська, Р. Нізамов, С.Л. Рубінштейн, Н. Тализіна, Г. Щукіна та інші. Як показали дослідження, в останні роки інтенсивно ведуть дослідження в Україні науковці: Н. Апатова, А. Верлань, Ю. Горошко, О. Жильцов, І. Іваськів, А. Пеньков, С. Раков, В. Руденко, С. Семеріков, В. Соловйов, I. Теплицький, Т. Чепрасова та ін.

Метою статті є розкриття тлумачення дефініції «критичного мислення» в історичному екскурсі.

В умовах бурхливого науково-технологічного розвитку кінця XX-го та початку XXI століття, суспільство, 3 одного боку, почало пожинати плоди такого «інтелектуального прориву», а з іншого, - усвідомлювати всю складність проблем, які з собою приніс цей постійно еволюціонуючий прогрес. Поява нових революційних технологій викликала до життя велику кількість нових напрямків у науці, поклала початок активним синергічним процесам. Багато нових відкриттів мають своєю появою на світ завдячувати саме таким несподіваним поєднанням наук. Кожна 3 окремо взятих наук торувала свій тернистий шлях по-своєму, накопичуючи свій фактичний матеріал, результати досліджень, наукові ідеї.

Керуючою силою творчих процесів був інтелект. Робота ж інтелекту завжди була упорядкованою, організованою, такою, що відповідала певним маловідомим правилам та законом. Архімедове «Еврика!» не було чимось випадковим, несподіваним одноразовим осяянням. За всіма його відкриттями стояла величезна інтелектуальна праця, спартанська дисципліна мислення. Саме критичне мислення - упорядковане, організоване, допомогло рухати науку і творити нові звершення.

Критичне мислення за своїм віком настільки ж давнє, як і його етимологія, і простежується до часів практики викладання і світогляду Сократа понад 2500 років тому, який винайшов методом пробного опитування той факт, що люди не можуть раціонально виправдати своєї впевненості щодо тих знань, якими вони володіють. Неправильно вжиті значення, недостатня кількість доказів або взаємосуперечливі переконання часто криються під привабливою, але значною мірою порожньою риторикою. Сократ довів той факт, що не потрібно залежати від «авторитетної думки», аби мати об'єктивні знання та здатність проникати в сутність речей. Філософ показав, що люди можуть мати владу і високий статус, але ж при цьому страждати від внутрішніх суперечностей i залишатися ірраціональними. Науковець довів важливість постановки глибинних запитань, які надають змогу глибоко зондувати мислення, перш ніж сприймати ідеї, гідні довіри. 
Також установив важливість пошуку доказів, уважно відстежуючи хід міркувань та припущень, аналізуючи основні поняття, рівно як відстежуючи не тільки те, що сказано, але й те, що зроблено. Метод опитування, створений ним, нині має назву «Сократове опитування» і $€$ найвідомішою стратегією навчання критичного мислення. У своєму режимі опитування Сократ підкреслив потребу в мисленні, яке відрізняється ясністю та логічною послідовністю. Автор визначив певний порядок традиції критичного мислення, а саме: обмірковано ставити питання стосовно загальноприйнятих переконань та роз'яснень, ретельно розрізняючи ті переконання, які $є$ аргументованими і логічними від тих, які - незважаючи на те, якими б привабливими для притаманного нам егоцентризму вони не були, все ж слугують нашим кровним інтересам, якими б комфортними чи втішними вони не були, - хибують відсутністю достатньої кількості доказів або раціональної основи, щоб виправдати наші переконання. Але Сократ був не єдиним, хто завзято проповідував ідею критичного мислення. Його найближчим послідовником став Платон, який сумлінно записував думки Сократа. Далі цю традицію наслідували Аристотель та грецькі скептики, які одностайно підкреслювали ту істину, що речі, зазвичай, суттєво різняться від тих, якими вони здаються, і що тільки підготовлений розум готовий до того, аби бачити крізь речі, які обернені до нас лише своєю поверхнею (оманливі вигляди) у порівнянні з тим, якими вони є насправді під своєю поверхнею (глибші реалії життя).

У подальшому давньогрецька традиція надихнула тих, хто прагнув зрозуміти глибші реалії буття, мислити системно, відстежувати наслідки ширше і глибше, оскільки тільки мислення, яке $\epsilon$ комплексним за своїм характером, аргументованим, і таким, що реагує на заперечення, зможе допомогти нам проникати під поверхню речей.

В епоху Середньовіччя традиції систематичного критичного мислення були втілені в працях і вченнях таких мислителів, як Фома Аквінський (Sumna Theologica), який, аби переконатися в тому, що його мислення відповідає найсуворішим випробуванням критичної думки, завжди систематично висловлював, уважно розглядав і відповідав на будь-яку критику його ідей, як необхідний етап в їх розвитку. Фома Аквінський збагатив нашу знання не тільки поширенням ідеї потенційної сили аргументації, але й постійної потреби культивування мистецтва аргументації та запровадження «перехресного допиту». Звичайно, міркування Фоми Аквінського також підтверджують той факт, що ті, хто критично мислить, не завжди відкидають загальноприйняті переконання, а тільки ті, яким бракує аргументованого підгрунтя.

Епоха Відродження (XV і XVI ст.) була позначена тим, що все більша кількість науковців у Європі почала переосмислювати своє ставлення до мистецтва, суспільства, природи людини, прав і свобод. Панівною стала думка, що аналіз та критика мають стати невід'ємними складниками в процесі осмислення в більшості галузей людського життя. Послідовниками вчень стародавніх науковців стали Коле (Colet), Еразм (Erasmus) і Myp (Moore).

На жаль, роль активного мисленнєво-пошукового процесу під час отримання знань була обмеженою, що непокоїло передових науковців того часу. Цю думку активно висловлював Френсіс Бекон (Francis Bacon). Він відверто визнав факт того, що розум не можна спокійно залишити на поталу його природних схильностей. У своїй книзі «The Advancement of Learning» («Про поліпшення навчання») науковець пропагує вивчення світу через емпіричний досвід. На думку цього видатного науковця, більшість людей, залишивши напризволяще власний розвиток, розвивають шкідливі звички мислення (які він назвав «ідолами»), що, в свою чергу, зумовлює формування переконань, які є помилковими або вводять в оману. Також автор звернув увагу на «ідолів племені» (способи, у які наш розум природно прагне обдурити себе), «ідолів ринку» (наше неправильне використання слів), «ідолів театру» (наша схильність потрапляти в пастку використовуючи звичайні системи мислення), та «ідоли школи» (проблеми мислення, викликані простим запам'ятовуванням правил та недосконалим навчанням). Книги Френсіса Бекона можна вважати одними 3 найбільш ранніх творів про сутність критичного мислення, його спосіб мислення певною мірою віддзеркалював традиційні канони критичного мислення.

Пізніше у Франції Декарт написав твір, який можна було б назвати другою роботою 3 критичного мислення, «Rules For the Direction of the Mind» («Правила для скерування розуму»). У цьому творі Декарт обстоював необхідність спеціального систематичного дисциплінування розуму задля його скерування в мисленні. Мислитель сформулювавйі обстоював необхідність наявності в мисленні ясності і точності. Декарт розробив метод критичного мислення, заснований на принщипі систематичного сумніву. Ним підкреслено необхідність базувати 
мислення на грунтовно продуманих основоположних припущеннях. Стосовно складників мислення, на його думку, необхідно ставити запитання, висловлювати сумніви й експериментувати.

У той же період часу сер Томас Мур (Thomas Moore) розробив модель нового соціального порядку, Utopia, у якій кожне поле діяльності в сучасному світі зазнавало критичного аналізу. Він натякав на те, що соціальні системи потребують радикального аналізу і критики. Критичне мислення цих науковців епохи Ренесансу і пост-Ренесансу відкрили шлях для появи науки i розвитку демократії, прав людини і свободи думки.

Гоббс і Локк (Hobbes and Locke) (XVI і XVII ст., Англія) продемонстрували аналогічну впевненість у критичному розумі мислителя, які ми знаходимо і в Макіавеллі. Жоден з них не прийняв традиційного стану речей, який домінував у мисленні тих часів.

Обидва прагнули критичного розуму, щоб відкрити нові перспективи навчання. Гоббс зайняв позицію натуралістичного погляду на світ, у якому все повинно бути поясненим за допомогою доказів та міркувань. Локк захищав побудований на здоровому глузді аналіз повсякденного життя i мисленнєвої діяльності. Науковець заклав теоретичні основи критичного мислення про основні права людини й обов'язки всіх урядів відповідати на аргументовану критику вдумливих громадян. Саме в цьому дусі інтелектуальної свободи і критичної думки, такі люди, як Роберт Бойль (Robert Boyle) в XVII-му столітті і сер Ісак Ньютон (Isaac Newton) в XVII-му і XVIII-му століттях зробили свою справу. У своєму творі «Sceptical Chymis»t, Бойль піддав різкій критиці хімічні теорії, що передували йому. Ньютон, у свою чергу, заклав далекосяжну основу, критично проаналізувавши традиційно усталені погляди на світ. Автор розвинув критичні думки таких геніїв, як Коперник, Галілей і Кеплер. Після Бойля і Ньютона ті, хто серйозно замислювався над довкіллям, визнали той факт, що необхідно відмовитися від егоцентричних поглядів на світ на користь поглядів, які базуються на ретельно зібраних свідченнях та розумній логіці.

Мислителі вісімнадцятого століття розширили наше розуміння критичного мислення ще далі, розвиваючи наше почуття могутності критичного мислення та його інструментарію. Стосовно проблем економіки, воно (критичне мислення) дало початок творові «Wealth of Nations» («Багатство Націй») Адама Сміта.

У XIX-му столітті сфера застосування критичної думки поширилась на галузь соціального життя людини Контом і Спенсером (Comte and Spencer). Розглядаючи проблеми капіталізму, критична думка поклала початок творам соціальної та економічної критики Карла Маркса. У галузі людської культури й основи біологічного життя, критичне мислення сприяло появі на світ твору Дарвіна «Походження людини». Стосовно вивчення підсвідомості критичне мислення знайшло своє відображення в роботах Зігмунда Фрейда. Стосовно досліджень у галузі культури воно сприяло створенню поля антропологічних досліджень. Стосовно мови воно сприяло виникненню лінгвістики і більш глибокого дослідження функцій символів і мови в житті людини. У XX-му столітті уявлення про природу влади і критичного мислення сприяли розробленню грунтовних теорій. У 1906 році Вільям Грем Самнер (William Graham) опублікував сенсаційне дослідження з основ соціології та антропології, Folkways, у якому він документально довів схильність людського розуму думати соціоцентрично і паралельну тенденцію шкіл слугувати (некритичній) функції соціального виховання: «Школи виховують всіх на один взірець, ортодоксальний. Шкільна освіта, якщо вона не керується найкращими знаннями та здоровим глуздом, буде виховувати чоловіків і жінок за одним шаблоном, як на токарному верстаті. Догматизм знаходить свій вияв у всіх великих доктринах життя. Він складається з найбанальніших виявів думки, які поширені в масах. Популярні погляди завжди містять омани, напівправду й узагальнення» [1, с. 630].

Самнер (Sumner) визнав необхідність глибокого критичного мислення в житті і в освіті, на його думку, критика $є$ детальним вивченням та перевіркою положення будь-якого роду, які пропонуються для прийняття задля з'ясування на предмет того, чи відповідають вони реаліям дійсності, чи ні. Критичне мислення $є$ продуктом освіти і постійного тренування. Це інтелектуальна звичка і міць, що є запорукою добробуту людини і становить єдину гарантія проти омани, обману, забобонів і нерозуміння себе і свого земного існування. Освіта $є$ якісною рівно настільки, наскільки вона допомагає розвинути критичні здібності. Педагог, який викладає будь-який предмет, i наполягає на точності i раціональному керуванні всіма 
процесами та методами, хто тримає все відкритим для необмеженої перевірки і ревізії, культивує цей метод як звичку у своїх учнів. Люди, які навчені цього, ніколи не будуть панічно тікати, не поспішають вірити, можуть розглядати речі як можливі або вірогідні до певного ступеню, без визначеності і без болю, можуть чекати на докази і зважувати докази, можуть чинити опір навіть притаманним їм забобонам.

Упродовж XX-го століття, яке знаменувало собою бурхливий науково-технологічний прорив, наука далеко сягнула уперед завдяки глибшому розумінню довкілля, побудованого на постулатах критичного мислення, запропонованих науковцями від сивої давнини до сьогодення. Відомий американський науковець, засновник сучасної школи критичного мислення Едвард Глейзер запропонував таке визначення терміна «критичне мислення»: «здатність критично мислити, як передбачено в цій роботі, охоплює три складники: 1) психологічна готовність розглядати вдумливо проблеми і питання, що входять до спектру власного життєвого досвіду; 2) знання методів логічного дослідження й аргументації; 3) наявність певних навичок у застосуванні цих методів. Критичне мислення вимагає наполегливих зусиль для дослідження будь-якого переконання чи уявної форми знання у світлі доказів того, що його підтримує та подальших висновків, до яких воно тяжіє. Воно також вимагає здатності вирізняти проблеми, знаходити реальні засоби розв'язання цих проблем, збирати й розташовувати в певному порядку необхідну інформацію, розпізнавати неявні припущення і давати оцінку, розуміти і використовувати мову з точністю, ясністю і чіткістю, тлумачити дані, давати оцінку доказам і оцінювати аргументи, визнавати наявність (або відсутність) логічних взаємозв'язків між твердженнями, робити виправдані висновки i узагальнення, перевіряти висновки й узагальнення, яких ми дійшли, реконструювати свої моделі переконання на основі ширшого досвіду, і висловлювати точні судження про конкретні речі і якості в повсякденному житті» [2].

Світ постійно змінюється і кладе початок новим реаліям у сучасній дійсності. Науковці всього світу активно вивчають світовий досвід, накопичений за багатовікове існування людства. Так, основи критичного мислення активно популяризуються й українськими науковцями. 3-поміж палких прихильників критичного мислення в Україні варто виокремити О. Тягла. У своїй статті «Деякі особливості інтелектуальної активності людини «швидкого» світу» [3] він зосереджує увагу на нагальну потребу «переформатування» освіти. Даючи досить короткий, але глибокий аналіз сфери освіти, автор підтримує зміни векторності освіти 3 інформативної на інструментальну. Саме інструменти пізнання світу допоможуть виховати той інтелектуально-вольовий потенціал мільйонів, який стане запорукою швидкого розвитку України та її подальшої євроінтеграції.

Реалії сьогодення вимагають миттєвої реакції на ті зміни, які постійно відбуваються у соціумі. Отже, активне впровадження в навчальні програми критичного мислення дозволять нашій країні швидко подолати відставання і зайняти почесне місце серед найрозвиненіших країн не тільки Свропи, а й світу.

\section{Література}

1. California Teacher Preparation for Instruction in Critical Thinking : Research Findings and Policy Recommendations / Richard Paul, Linda Elder, and Ted Bartell ; State of California, California Commission on Teacher Credentialing, Sacramento. - March, 1997. 2. Glaser E. M. An Experiment in the Development of Critical Thinking / Edward M. Glaser. - Teacher's College, Columbia University, 1941. 3. Тягло О. В. Деякі особливості інтелектуальної активності людини «швидкого» світу / О. В. Тягло // Вісник ХНУ імені В. Н. Каразіна. Серія «Філософія. Філософські перипетії». - 2012. - № 992.

Олеся Мегем

\section{МОДЕРНІЗАЦІЯ ШКІЛЬНОЇ БІОЛОГІЧНОЇ ОСВІТИ В УКРАЇНІ У ДРУГІЙ ПОЛОВИНІ 60-х - СЕРЕДИНІ 80-х РОКІВ ХХ ст.}

Мегем О. М. Модернізація шкільної біологічної освіти в Україні у другій половині $60-\mathrm{x}-$ середині 80 -х років XX ст.

У статті шляхом здійснення аналізу стратегії руху суспільного середовища в досліджуваних хронологічних межах визначено провідні орієнтири розвитку шкільної 